\title{
SOBRE EL DEBER ACADÉMICO
}

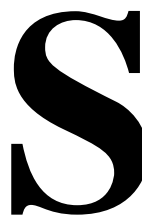

e han cumplido tres cuartos de siglo desde que un grupo de biólogos visionarios decidió fundar la sociedad que nos une y reune. Veinticinco años atrás, nuestro expresidente Tito Ureta, editorializaba Quo Vadis societatis? En un ensayo lúcido, Tito hacia predicciones sorprendentemente atinadas sobre hacia donde se dirigía nuestra Sociedad. Sin advertirlo, Tito tenía entre su audiencia a un aspirante a biólogo recién incorporado a la Sociedad: el que escribe estas líneas. Sin saberlo, o sabiéndolo, Tito estaba creando una vocación de servicio. Un cuarto de siglo después, me toca asumir lo que otro expresidente, Luis Vargas, ha llamado “...cumplir con éxito la gran tarea en esta 'carrera de postas' de los Presidentes de la Sociedad." Y también me corresponde ser el segundo ecólogo que alguna vez haya ocupado este distinguido cargo, que con prestancia supo llevar Ernst Hajek hace ya una década. Investido con este privilegio y aprovechando esta tribuna, me permito compartir con nuestros socios algunas reflexiones sobre el deber académico y societario.

Empecemos por conceder que en Chile mucho se enfatiza la libertad académica, que es la libertad de investigar y enseñar sin censura. Y que poco se discute sobre el deber académico, que involucra el deber de crear y transmitir conocimiento nuevo, pero también el deber de participar activamente en una comunidad académica extramural, como es, en este caso, nuestra Sociedad de Biología de Chile.

Al respecto, me da la impresión que todos concordamos en que un científico que no genera (o no descubre) y que no disemina (o no publica) conocimiento original, no está cumpliendo con su deber básico de científico. Este es el deber número uno. Se es científico no por haber adquirido un grado alguna vez, sino por ejercer dicha ciencia constantemente. Por lo mismo, creo que todos estamos de acuerdo en que un docente que no es eficaz (es decir, que no enseña bien), no cumple con su mínimo deber de docente. Este podría ser el deber número dos. ¡Qué puede haber peor que un docente que en vez de motivar, mata vocaciones!

Tal vez hay menos acuerdo, o menos conciencia, de que hay más deberes académicos que los recién enumerados. Sigamos entonces. Otro de los deberes académicos es ser un mentor o tutor de nuevos científicos, es decir, formar las generaciones de reemplazo de uno mismo. Este tercer deber es casi una necesidad, por razones obvias. Un cuarto deber académico, bastante poco glamoroso e incomprendido, es participar de la vida académica intramural y dedicar tiempo a administrar para que otros puedan disponer de tiempo y recursos para hacer ciencia, docencia y tutoria. Ya vamos en cuatro deberes, pero hay más aún.

Ineludible es el destinar tiempo para revisar y editar trabajos y propuestas de colegas y estudiantes, ya sean de investigación o de tesis. A este quinto deber yo lo llamaría servir a la comunidad de científicos formados y en formación. El deber número seis consiste en difundir el valor de la ciencia a la comunidad extramural que la financia. Es decir, divulgar a los legos por qué la ciencia sirve no sólo a los científicos y cómo su valor se propaga a la comunidad nacional que la sustenta con sus impuestos y alienta con sus esperanzas.

Un séptimo deber es participar de la vida societaria nacional e internacional. Es decir, colaborar e integrarse. Voy a saltarme la parte internacional, porque los beneficios de dicha integración son demasiado patentes. Más bien, voy a referirme brevemente a participar de la vida societaria nacional, que es la que nos congrega durante cada reunión anual de biólogos. No se trata de darnos más importancia de la que merecemos. De hecho, las reuniones societarias muchas veces constituyen la hoguera de las vanidades y la vacunación contra la soberbia. Pero tampoco se trata 
de descalificarse en el necesario papel de modelo de los pares, de los científicos en formación y de los estudiantes. Es mezquino negarse a comparecer al foro de los pares y defenderse con la fuerza de los argumentos. No es inspirador de las generaciones de reemplazo el rehuir el debate y abstenerse de proponer ideas o críticas. Nadie de nuestra sociedad debiera desvalorizarse tanto como para pensar que no es modelo para alguna vocación científica en desarrollo. Dicho brevemente, nadie debe negar su presencia en las reuniones societarias, porque cada uno de nosotros representa un modelo y un aporte. No sabemos cuándo ni cuánto cosecharemos con nuestro accionar societario, pero sí sabemos que si no sembramos, nada emergerá. Es por ello que debemos estar presentes en cada reunion anual: para sembrar una y otra vez.

Todo lo anterior parece obvio en el pensamiento, pero no siempre se traduce en las acciones. Me da la impresión que existe demasiado celo en promover la libertad académica y poco celo en cumplir con los deberes inherentes. Este desbalance configura una receta letal para fabricar científicos aislados que actúan como divas y que no dejan descendencia fértil, sino cortesanos, aduladores e intelectos castrados. En mi opinión, lo que se requiere son académicos que integren comunidad, en que el saber se disemine no sólo a través de publicaciones y cursos sino de interacciones personales y grupales. Para eso nos convocamos año a año en el ritual de comunicar en qué estamos y a quiénes estamos formando. Y para servir de ejemplo del deber académico.

FABIAN JAKSIC, PRESIDENTE

Sociedad de Biología de Chile 